精神保健センターの電話相談における

継続相談についての研究 I

一統計を中心とした考察—

本多 正喜* 城田 陽子* 金子 鈴* 高橋 滋*

\title{
A Study on Continuing Telephone Consultations at Gunma \\ Prefectual Mental Health Center Following \\ in-Center Consultations: \\ Prat I-Statistics
}

\section{Masaki HONDA*, Yoko SHIROTA*, Suzu KANEKO* and Shigeru TAKAHASHI*}

We studied 388 cases who have consulted by telephone twice or more, and were selected from records kept at the Gunma Prefectural Mental Health Center since its opening (1986) until March 1993.

For many cases, such series of consultations ended after no more than four calls, but 19 cases have lasted over several years or over a hundred calls. The most frequent type was related to mental illness of various sourts; the second most frequent concerned problems of children. Among the first type, many cases had visited psychiatric hospitals or clinics, increasing percentage wise as they passed the stages of their condition; first, anxiety overhaving fallen mentally ill; second, dissatisfaction or doubt about psychiatric treatment; third, anxiety over rehabilitation. Many cases felt completely at a loss over difficulties in finding solutions to their problems even after consulting with mental hospitals, clinics, or other counseling facilities. Cases continually used telephone for a sense of ease and/or familiarity with counselors of the Center.

It was suggested that these continuing telephone consultations followed public relations that the Center's services were available without charge, and especially that they were so easily accessible by telephone.

Key words: mental health center, telephone consultaiton, continuation, a sense of ease, a sense of familiarity 精神保健センター, 電話相談，継続性，安心感，親近感

* 群馬県精神保健センター

* Gunma Prefectural Mental Health Center 


\section{I 緒言}

1906年 Warren, H.M. 牧師がニューヨークで国 民人命救助同盟を創設し，市民からの相談を受け つけたときに相談方法の一つにまで高められるこ とになった電話相談は，1953年ロンドンでのサマ リタンズによる24時間体制の電話相談へと発展 し，1960年に国際緊急電話相談連盟の誕生へとつ ながった歴史をもっている。

わが国では1971年東京におけるいのちの電話の 活動が電話相談の始まりといえ, その歷史は僅か 20数年にすぎない. 現在ではいのちの電話を中心 に電話相談活動が活発化し，1988年に全国電話相 談研究会の発足をみてからは研究報告も増えつつ ある(植木ほか, 1981; 有田ほか，1994）。しかし これまでに報告されている精神保健センターの電 話相談に関するまとまった調查は，新規の相談に 関するものに限られている（石原ほか，1991；本 多ほか, 1994)。

群馬県精神保健センターの電話相談も昭和 61 年 1 月の開所以来 7 年余を経過し, 相談員の間には 繰り返し電話相談をしてくる事例と, 相談が 1 回 で終了する事例とでは，その電話相談の利用の仕 方に違いがあるらしいとの認識が深まりつつあ る.そこで今回われわれは当センターで受けつけ た電話相談の中から，特に継続的な電話相談をと りあげてその特徴を調查したので，ここに報告す る.

\section{II 対象と方法}

当センターでは, 電話回線を相談専用に 3 回線 設置している，今回ここでいう電話相談とは，前 報（本多ほか，1994）と同様に，この 3 回線を利 用して「悩みをもつ人が，匿名で，どこからでも， 即時に, 直接出向くことなく, 電話を利用して, 当センターの相談員にアドバイスを受けて悩みを 解決していこうとする相談の一形態であり, 当セ ンターの電話で相談に応じるのが不適当と考えら れる場合には，他の相談機関や治療機関を紹介す ることもあれば，当センターの面接相談につなげ
ることもある相談活動」をさすものとする．なお 当センターで電話相談に携わっている者は, 心理 臨床家，保健婦ならびにケースワーカーであり， ときに精神科医が受けることもあるが数は少な い.

われわれは昭和 61 年 1 月の当センター開所から の電話相談記録票をもとに, 当センターのデイケ ア通所者，および定期的な来所相談を受けている 者からの相談を除いた, 開所から平成 3 年度末(平 成 4 年 3 月）までの電話相談事例について，新規 と継続の別, 相談者の続柄と性別, 相談者からみ た対象者の続柄およびその性別と年齢, 相談経路, 相談内容, 相談員の対応方法, 相談時間，そして 明らかな場合は相談者あるいは対象者の氏名と住 所等を調べ，調查研究用の台帳を作成した（本多 ほか, 1994).今回この台帳に，同様の手続きで調 べた平成 4 年度分（平成 4 年 4 月〜同 5 年 3 月) のデータを追加した。

この台帳から，氏名，住所，年歯あるいは相談 内容といった複数の情報によって対象者を同定し 得た事例を選び出し，2 回以上当センターに電話 相談をもちかけてきた事例を「継続相談」と定義 した．これ以後「継続相談」と表記する場合は, 対象者を同定し得た継続相談事例をさすものと し，対象者を同定し得なかった事例は今回の調査 から除外した。すなわち母親または父親が子ども (対象者)のことで相談してきた場合，さらに子ど もが自分 (対象者)のことで相談してきた場合は， いずれも同じ対象者についての相談であるため, このような相互関係にある相談は一連の継続相談 とみなした。

以上の手続きによって選ばれた継続相談につい て，今回は主に統計的な観点からその実態を明ら かにした，当センターでは相談内容を，全国の精 神保健センター長会で定めている基準に従って26 項目に分類している．前報（本多ほか，1994）で は,これらを「精神障害の問題」「食欲の異常」「児 童生徒の問題」「家庭内の間題」「心気症的悩み」 「対人関係の悩み」「職場の問題」「性格の悩み」「性 の悩み」「老人の問題」「社会的問題」「その他」の 
12項目にまとめ直して分類した.今回は事例数の 少ない項目を更に一括し，「食欲の異常」を「精神 障害の問題」に,「老人の問題」と「社会的問題」 を「その他」に含め, 合計 9 項目にまとめ直した. なお電話と来所による両方の相談を受けた事例 では, 来所相談後も継続的に電話相談をしてくる 事例を調査対象とし，来所相談後に電話相談をし なくなった事例は除外した。

\section{III 結 果}

（1）相談回数の継続相談事例数

当センターの開所から平成 4 年度末までの 7 年 3 か月間に受けつけた継続的な電話相談の総数は 1,940件であった.これは同一期間内の新規相談と 継続的な相談とを合計した電話相談の総数 7,049 件中の $27.5 \%$ 占めた.

一方氏名，住所，年齢等の複数の情報によって 同定し得た継続相談事例の総数は388名であった. これらの者からの継続相談の総数は1,634件であ り,これは継続的な電話相談の総数 1,940 件中の 84.2\%を占めた。裏を返せば, 306件, $15.8 \%$ の継 続的な相談については継続相談であるか否かを同 定し得なかった。

表 1 に示すように継続相談回数 2 回までで相談 が終了した事例が 212 件， $54.7 \%$ と過半数を占め た.ついで 3 回までの 63 件, $16.2 \%$ が続き， 4 回 までが40件， $10.3 \%$ であった。これら継続相談回 数 4 回までで相談を終了した事例数は 315 件で, 全 体の $81.2 \%$ 占めた。このように継続相談は相談 回数が増すごとに事例数が減少し, 大半は 4 回目 までで相談が終結する傾向を示した。

また継続相談の回数は $2 \sim 112$ 回 (Median $=2$ 回), 継続期間は 1 日から最長 7 年 (Median $=0.1$ 年）で，回数，期間ともに事例によって大きな開 きがあった。

（2）初回相談時の相談内容別の継続相談事例数 継続相談の初回相談時の相談内容を表 2 のよう に分類した。それれ゙れの相談内容を説明すると， 「精神障害の問題」では向精神薬の副作用の心配や 受診するための具体的方法を問う内容であり,「児
表 1 相談回数別の継続相談事例数（単位：件）

\begin{tabular}{cr}
\hline 相談回数 & 事例 $(\%)$ \\
\hline 2 回 & $212(54.7)$ \\
3 回 & $63(16.2)$ \\
4 回 & $40(10.3)$ \\
5 回 & $19(4.9)$ \\
6 回 & $9(2.3)$ \\
7 回 & $7(1.8)$ \\
8 回 & $4(1.0)$ \\
9回 & $7(1.8)$ \\
10回以上 & $27(7.0)$ \\
\hline 合 計 & $388(100.0)$ \\
\hline
\end{tabular}

(注) 相談回数 1 回の事例数は 5,109 件で ある

童生徒の問題」とは不登校や非行に関するもの, 「家庭内の問題」とは配偶者や姑への不満などに関 するもの,「心気症的悩み」とは動悸や頭重など, 「対人関係の悩み」とは近所付き合いや友人関係で のトラブルに関するもの，「職場の問題」とは上司 や部下あるいは同僚との軋軪など，「性格の悩み」 とは「思ったことがいえない」「大勢の人の前で緊 張しやすい」などといった内容のもの,「性の悩み」 とは性器やセックスに関する悩みや疑問が中心で あり，「その他」とは借金や経済問題など上記相談 内容に含めて考えられない内容であった. 当セン ターの電話相談には, 作話やテレホンセックスと いったおよそ相談とはいえないような電話もか かってくることがある.このような電話をかけて くる者は, その都度年齢や話の内容を変えること が多く，同じ者からの電話であると同定すること が困難な場合が多い。しかし中には同一事例と同 定できる電話もあり，このような電話は相談とは いい難いが，数が少なかったので今回は「性の悩 み」に含めて集計した。

表 2 に示すように「精神障害の問題」を訴える 事例が最も多く，ついで「児童生徒の問題」を訴 える事例が多く，この 2 つの相談内容で全体の $68.8 \%$ 占めた。初回相談時の相談内容別の継続 相談回数では, いずれの相談内容でも相談回数が 増加するにつれて事例数は次第に減少した。

継続相談回数が 2 回で終了した事例は，2 回目 
表 2 初回相談時の相談内容別の継続相談事例数（単位：件）

\begin{tabular}{|c|c|c|c|c|c|c|c|c|c|c|c|}
\hline \multirow{2}{*}{ 相談内容 } & \multicolumn{4}{|c|}{ 相 } & 談 & \multirow{2}{*}{$\begin{array}{l}\text { 回 } \\
7 \text { 回 } \\
\end{array}$} & \multicolumn{3}{|l|}{ 数 } & \multirow{2}{*}{ 合計 } & \multirow{2}{*}{ (\%) } \\
\hline & 2 回 & 3 回 & 4 回 & 5 回 & 6 回 & & 8 回 & 9 回 & 10 回以上 & & \\
\hline 精神障害の問題 & 124 & 26 & 27 & 9 & 6 & 3 & 3 & 5 & 17 & 220 & $(56.7)$ \\
\hline 児童生徒の問題 & 28 & 9 & 4 & 3 & 0 & 1 & 0 & 0 & 2 & 47 & $(12.1)$ \\
\hline 家庭内の問題 & 12 & 6 & 2 & 2 & 0 & 0 & 0 & 0 & 1 & 23 & $(5.9)$ \\
\hline 心気症的悩み & 12 & 3 & 2 & 0 & 2 & 0 & 0 & 0 & 1 & 20 & $(5.2)$. \\
\hline 対人関係の悩み & 11 & 6 & 1 & 0 & 0 & 0 & 0 & 0 & 0 & 18 & $(4.6)$ \\
\hline 職 場 の 問 題 & 7 & 1 & 1 & 0 & 0 & 0 & 1 & 0 & 2 & 12 & $(3.1)$ \\
\hline 性 格 の 悩 み & 3 & 3 & 1 & 0 & 0 & 1 & 0 & 1 & 1 & 10 & $(2.6)$ \\
\hline 性 の 悩 み & 7 & 1 & 0 & 1 & 0 & 0 & 0 & 0 & 1 & 10 & $(2.6)$ \\
\hline そ の & 8 & 8 & 2 & 4 & 1 & 2 & 0 & 1 & 2 & 28 & $(7.2)$ \\
\hline 合 & 212 & 63 & 40 & 19 & 9 & 7 & 4 & 7 & 27 & 388 & $(100.0)$ \\
\hline
\end{tabular}

の相談のほとんどが 1 回目の相談で相談できな かった点を補ったり，相談員による助言を実行し てみた結果を報告し，その後のことについて新た な助言を求めて終了するものであった。一方 3 回 以上の事例では初回相談時の訴えを繰り返した り，新たな事柄について相談しようとするものが 多く，その相談の継続性に違いが認められた。そ こで各相談内容別に，継続相談回数が 2 回で終了 した事例と 3 回以上の事例とに分けて検討する と，3 回以上継続した事例で割合が高かった相談 内容は「性格の悩み」に関するもののみで，その 他の内容は 2 回で終了した事例の方が多かった。

（3）相談回数別の継続相談事例の来所相談歷の

\section{有無}

前項と同様の理由から，継続相談回数が 2 回で 終了した事例と 3 回以上の事例とに大別して検討 した．表 3 に示すように，継続相談回数が 3 回以 上の事例には, 当センターへの来所相談歴を有す る者について相談してくる事例の割合が有意に高 かった $\left(\chi^{2}=9.13, \mathrm{p}<0.01\right)$.

（4）初回相談時の相談内容別の継続相談事例の 精神科治療歴の有無

表 4 に示すように「児童生徒の問題」をはじめ, 多くの事例では精神科治療歴を有しない者につい て相談してくる事例の割合が高いが,「精神障害の 問題」では逆に治療歴を有する者について相談し てくる事例の割合が高かった。この中で特に事例
表 3 相談回数別の継続相談事例の来所相談歴の 有無 (単位：件)

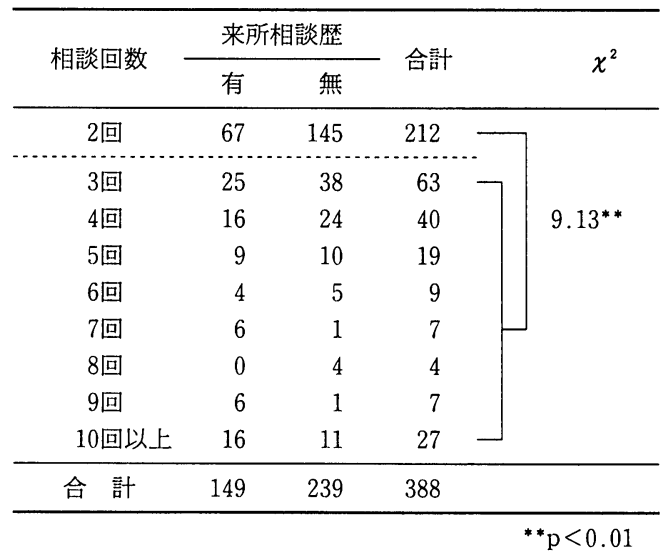

数の多い「精神障害の問題」とそれ以外の相談内 容とに分けて比較すると，「精神障害の問題」は精 神科治療歷を有する者について相談してくる事例 の割合が有意に高かった $\left(\chi^{2}=53.69, \mathrm{p}<0.001\right)$.

（5）「精神障害の問題」の細分類別の継続相談 事例の精神科治療歴の有無

「精神障害の問題」を「精神障害ではないかと の心配」,「精神障害の治療の問題」，「社会復帰の 問題」に細分類した。「精神障害ではないかとの心 配」とは「兄が，人が自分の悪口をいっている， といっている」「子供がこの頃部屋に閉じこもって 出てこない」などの相談であった，「精神障害の治 療の問題」は「子供が薬をのもうとしない」「父親 
表 4 初回相談時の相談内容別の継続相談事例の 精神科治療歷の有無（単位：件）

\begin{tabular}{|c|c|c|c|c|c|}
\hline \multirow{2}{*}{ 相談内容 } & \multicolumn{2}{|c|}{ 治療歴 } & \multirow{2}{*}{ - 合計 } & \multirow{2}{*}{$(\%)$} & \multirow{2}{*}{$\chi^{2}$} \\
\hline & 有 & 無 & & & \\
\hline 精神障害の問題 & 158 & 62 & 220 & $(56.7)-$ & \multirow{9}{*}{$53.69^{* * *}$} \\
\hline 児童生徒の問題 & 7 & 40 & 47 & $(12.1) \square$ & \\
\hline 家庭内の問題 & 6 & 17 & 23 & ( 5.9$)$ & \\
\hline 心気症的悩み & 9 & 11 & 20 & $(5.2)$ & \\
\hline 対人関係の悩み & 10 & 8 & 18 & $(4.6)$ & \\
\hline 職 場 の問題 & 3 & 9 & 12 & $(3.1)$ & \\
\hline 性格の悩み & 4 & 6 & 10 & $(2.6)$ & \\
\hline 性 の 悩み & 5 & 5 & 10 & $(2.6)$ & \\
\hline そ の 他 & 14 & 14 & 28 & $(7.2)-$ & \\
\hline 計 & 216 & 172 & 388 & $(100.0)$ & \\
\hline
\end{tabular}

表 5 「精神障害の問題」の細分類別の継続相談 事例の精神科治療歴の有無（単位：件）

\begin{tabular}{crrrrr}
\hline \multirow{2}{*}{ 相 談 内 容 } & \multicolumn{3}{c}{ 治療歴 } & \multirow{2}{*}{ 合計 } & $(\%)$ \\
\cline { 3 - 5 } & 有 & 無 & & \\
\hline 精神障害ではないかとの心配 & 15 & 49 & 64 & $(29.1)$ \\
精神障害の治療の問題 & 112 & 13 & 125 & $(56.8)$ \\
社会復㷌の問題 & 31 & 0 & 31 & $(14.1)$ \\
\hline \multicolumn{1}{c}{ 合 } & 計 & 158 & 62 & 220 & $(100.0)$ \\
\hline
\end{tabular}

が病院にかかって長くなるが一向によくならな い」といった治療への不安, 疑問に関するもので, 「社会復帰の問題」は「子供をデイケアに通わせた い」「子供が退院して勤め始めたが，すぐに会社を やめてしまった」といった内容であった.

表 5 に示すように,「精神障害ではないかとの心 配」では，精神科の治療歴を有しない者について 相談してくる事例が多かった。しかし「精神障害 の治療の問題」では，精神科治療歴を有する者に ついて相談してくる事例が圧倒的に多かった. 当 然のことながら，「社会復帰の問題」では精神科治 療歷を有する者について相談してくる事例のみで あった。

\section{IV 考 察}

電話という機器の特徴についての論考（藤竹, 1989), 電話相談利用者の実数をもとに精神保健セ
ンターにおける電話相談の実態について調査した 報告(石原ほか，1991），延べ件数をもとに児童相 談所における電話相談の利用の実態をまとめた調 查(小林, 1992), 電話相談一般についての方法論 を考察したもの（長谷川，1990；長谷川，1992）, あるいは精神保健センターにおける電話相談の フォローアップ調査の結果をまとめたもの（岩崎 ほか，1984）などは，これまでにも報告されてい る。しかし本報のように, 継続相談事例の電話相 談の利用の実態について複数の観点から統計的に まとめた調查は, 精神保護センターの調查も含め て本邦ではこれまでに報告されていない，それは 後述するように, 多くの事例が匿名で相談してく るために事例を同定することが容易でないためと 考えられる.

\section{【継続相談の同定について】}

今回のわれわれの調査では，昭和61年 1 月の当 センター開所以来，平成 5 年 3 月末までの電話相 談総数に占める継続的な相談の比率は $27.5 \%$ で あった，精神保健セン夕ーに扔ける電話相談につ いて，新規相談と継続的な相談の構成比を論じた ものには，石原ほか（1991）が挙げられる，彼ら は1986年から1990年までの電話相談総数に占める 継続的な相談の割合がほぼ12〜19\%で推移してい ると述べているが，これは当センターよりも少な い. 彼らは新規相談と継続的な相談の構成比につ いては単に数値を挙げたにとどまっており，また 電話相談の実施方法についても何ら記述していな いので，この両者の差がどのような要因によって 生じているのかは明らかにし難い. 当センターに 限っていえば，個々の電話相談を終える際，相談 者に対して必要に応じ「また困ったらこの電話を ご利用ください」といったことも話しているので, このような相談の終了の仕方が継続的な相談を増 加させた一因になっているとも考えられる．当セ ンターにおける継続的な電話相談の実際の構成比 は前掲した27.5\%よりさらに高いはずであるが， 事例の多くが匿名で相談してくるために, 継続相 談であることが明らかでない場合のあることや， 
相談者自身が過去に当センターに電話相談をした ことがあるかどうか記憶が曖昧であることなどに より，継続的な相談すべてを同定することは困難 であった。

\section{【当センターにおける継続相談事例の特徵につ} いて】

相談回数と継続相談事例数の関係では, 相談回 数が増すごとに事例数は減少し, 大半は相談回数 4 回までで相談が終結している，したがって事例 が抱えている問題や悩みは, 数回相談することで その時点での何らかの決着をみるものと考えられ る.しかし数年以上にまたがって継続している事 例や, 相談回数が100回以上を数える事例も19事例 あることからは，なかなか問題が解決に至らずに 繰り返し相談を求めてきている事例の存在が窅わ れる.一般に電話相談では現在までのところ明確 な定義はないが，このような事例は「常習通話者」 (Lester, D. \& Brockopp. G.W., 1982) とか「常 習的かけ手」(有田ほか，1986），あるいは「頻回 通話者」(有田, 1993) と呼ばれており，その対応 に苦慮することも少なくない.

この繰り返し電話をかけてくる継続相談事例 は, それ相応の特徵をもっている. その特徵につ いては, まず最初に初回相談時の相談内容との関 連から述べる．われわれは前報(本多ほか，1994） で, 新規相談事例の相談内容で最も多いのが「精 神障害の問題」で，ついで「家庭内の問題」と「児 童生徒の問題」が多いことを報告した。しかし今 回の調査対象である継続相談事例で, 初回相談時 に訴えられる相談内容はこれと様相を異にしてい る.すなわち継続相談事例も, 初回相談時には「精 神障害の問題」で相談してくることが最も多いと いう点では新規相談事例と同様であるが，第 2 位 は「児童生徒の問題」で, これら以外の相談内容 は極端に少なかった。したがって新規相談に占め る割合の多い「家庭内の問題」は継続相談にはな りにくいようである．前報（本多ほか，1994）で 述べたように, 当センターは住民からは精神障害 に関する専門的な相談機関として認知されてい
る.「精神障害の問題」に関する継続相談では, そ の「治療」に関する不安, 疑問, 不満などが訴え られているにとどまらず, 精神障害者を抱える家 族が精神障害者に対してどのように接したらいい のか困惑して電話をかけてくる場合も少なくな い。この場合に訴えられる内容は，例えば「朝起 きなさいといってもいいんでしょうか」手伝いを するようにいってもいいんでしょうか」いつまで も働こうとしないんですけど，このままでいいん でしょうか」などといった，日常生活上の細々と したことについての相談である. 加えて精神障害 者が訴える症状で, 内科や婦人科等の精神科以外 の診療科目に入る相談も, 当センターの電話相談 に寄せられている。すなわち継続相談には精神科 治療から発展してくる諸々の問題について, 広範 囲の相談が奇せられているといえる.

以上のような理由から, 当センターの電話相談 では「精神障害の問題」に関する継続相談が多く なっていると考えられる．また「児童生徒の問題」 の中では不登校に関する相談が過半数を占めた が,この種の問題も「精神障害の問題」に近接す る内容であることから, 継続相談が多くなってい るものと考えられる．ただし精神科治療の範疇に ある問題とはいえ，「飲酒に関する問題」での継続 相談事例が少ないのは, 現在のアルコール依存症 およびその関連領域の問題の治療では, Alcoholic Anonymous, すなわち AA と呼ばれる「匿名断酒 会」の集会の場が利用されやすいことや, AKK と 呼ばれる「アディクション問題を考える会」のミー ティングやセミナーが数多く行われていること, さらに断酒会も存在するなど, セルフ・ヘルプ・ グループによって継続相談事例が支えられている という実情があるものと考えている.

第 2 に相談回数と当センターへの来所相談歴の 有無との関係では, 相談回数が 2 回で終了した事 例に比べて 3 回以上の事例の方が, 来所相談歷を 有する者についての相談の割合が高かった。この ことについてはいくつかの理由が考えられる。一 つは相談員が当センターに実際に来所した相談者 に対して, 特に電話相談とは断わっていないもの 
の「ご相談があればまたどうぞ」と，当センター に対する相談者の敷居が低くなるような対応をし ていることがあげられる.また相談者が当セン ターに来所して実際に建物をみたり, 相談員に直 接会って安心し，より相談しやすくなるという点 も見逃せない. 公的相談機関には特に利用者に とっての敷居の低さが求められるため, このよう な相談員の援助姿勢が継続相談回数を増加させる 一因になっていることも考えられよう.

この相談回数と来所相談歴との関係では, 継続 的に相談せざるを得ない継続相談事例の抱えてい る問題の複雑さにも注目しなければならない. 稲 村（1979）はいのちの電話に精神科医療面接室が 併設されることになった経緯について，いのちの 電話の医療相談で専門医が応じても, あるいは電 話による対応だけでは十分でないとして他機関を 紹介しても，また繰り返し電話をしてくる事例が 後を絶たなくなってきたからであると述べると共 に, このような事例は種々の機関を転々とした結 果, 精神科医療面接室を訪れており, 通常用いら れている精神科の診断名だけではまとめ切れない ような複雑な問題を抱えている困難な事例が多い と述べている. 電話相談の条件は相互に異なって いても, 電話相談に加えて面接相談も行っている という点では, このいのちの電話も当センターも 同様である.このことを考えると, 繰り返し相談 してもなお問題が解決しないために, 当センター に来所してきているという事例の実態が浮かびあ がってこよう. 実際当センターで受けつける電話 相談には，様々な相談機関や医療機関を訪れた後 に,さらに当センターに電話をかけてくる事例は 少なくない.

第 3 に継続相談と精神科治療歴との関連につい ては, 治療段階という視点から整理することが可 能だろう。まず「精神障害ではないかとの心配」 の段階で電話してくる事例には, 精神科の治療歴 を有する者についての相談は当然のことながら少 ない.この段階でわれわれ相談員は, 当センター への来所相談を勧めたり, 直接精神科医療機関に 受診するよう助言することもある.したがって相
談者の当座の不安や疑問は, どこかの相談機関あ るいは医療機関につながることで解消し，電話相 談もその時点で当座の終結をみることになるもの と思われる。ついで精神障害であることがはっき りして「治療」を開始した段階での相談となると, 圧倒的に精神科での治療歴を有する者についての 相談が多くなる．この段階で精神科の治療を受け ていない者についての相談が存在するのは, 相談 者が家族以外の者の場合, 対象者の精神科治療歴 の有無をはっきりとは知らないことによるもので あり, 現在治療中か否かは別として, 少なくとも 過去においては精神科の治療を受けたことがある ものと推定される.この段階では治療の長期化に よって医療に対する不安や不信が昴じ, その都度 疑問に答えてくれる機関に相談しようとする気持 ちが強まるので, 電話相談が継続的な性質を強め てくるといえるだろう。その後のデイケアを含め た「社会復帰」段階の相談になると, 精神科の治 療歴を有しない者に関する相談は皆無となる.こ の段階では何らかの社会復帰のルートに乗ること で不安が低減されるため, 電話相談の継続性が弱 まってくるのであろう。このように特に「治療」 の段階にある事例からの相談が繰り返されやすい ため, 精神科治療歷を有する事例の方が継続相談 回数が多くなるものと考えられる. 以上のように 継続相談回数と精神科治療歴の有無との関係につ いては, 治療がどの段階にあるかという条件の違 いによって明白な傾向が認められる.

一方「児童生徒の問題」を訴える継続相談事例 に, 精神科治療歷を有する者についての相談の比 率が低かったことについても述べておかなければ ならない.「児童生徒の問題」の中では不登校に関 する相談が過半数を占めて多かったことは既述し た通りである，不登校の児童生徒は身体症状を訴 えることが非常に多く，そのために精神科医療機 関よりも，まず小児科や内科を受診するのが通常 であり，その後に児童相談所や教育相談所等に連 れられて行くことが多い. 白井（1979）はいのち の電話に併設された医療相談で医師の診察を受け た事例についてまとめた報告の中で, 治療群 
（52\%）と末治療群 (48\%) がほほ半数ずつを占め, 診療科目では精神科, 内科, 産婦人科などが多く, 外科系が少ないと述べている．今回のわれわれの 調査で,「児童生徒の問題」で精神科治療歷を有す る者についての相談の割合が低かったのは同様の 実態があるものと考えられ，これらの事例がいか なる治療機関や相談機関にも行ったことがないと いうことを意味しているのではない.

\section{【当センターの電話相談における継続性の意味 について】}

近年心身の不調を訴える者が増え, 精神科の外 来はどこも込み合っている．このような事情もか らみ，主治医は患者が相談したいときすぐに，あ るいは十分時間をとって相談に応じられるとは限 らない. 当センターでは複数の相談員が交替でと いう条件下ではあるが，随時電話相談に応じる態 勢をとっているので，相談者は「相談したいとき に相談にのってもらえる」「どんなことでも相談に のってもらえる」という意識をもちやすい.「たび たびですみませんが…」「つまらないことですみま せんが…」という相談者の言葉は，そのことを端 的に物語っているといえるであろう。

電話をかけるのも切るのも相談者の意志ででき るという「かけ手主導性」，予約せずに相談が可能 という「即時性」, 相談機関に直接出向かなくても 相談できるという「超地理性」,「匿名性」, 電話料 金を負担するだけで済むという「経済性」(長谷川, 1992）といった電話そのもののもつ多くの特質が, すでに相談の継続性を強く促すものになってい る.また前述した当センターへの来所相談による 安心感や相談員に対する親近感も, 電話相談の継 続性を強める一因となっていよう．特にこの安心 感や親近感については電話相談一般に関していわ れている匿名性による相談のしやすさとは異質な ものであるといえよう.

以上の考察から，当センターにおける継続相談 事例は複数の医療機関や相談機関を訪れていなが ら，その抱えている問題の複雑さや困難さに困惑 し, 当センターに対する安心感や親近感あるいは
相談のしやすさから継続的に電話をかけてきてい るといえるだろう。このことに関しては，当セン ターが電話相談にも来所相談にも無料で応じる公 的相関機関であることを PRしていることや，特 に電話相談については随時受けつけるとうたって いることが大きく影響していると考えられる。か け手主導性」「即時性」「超地理性」といった電話 のもつ一般的特性がそこに底流していることは改 めて強調するまでもなかろう。

なお今回の調査の過程で，継続相談事例を個別 にみた場合, 電話相談の利用の仕方がそれぞれに 異なっているという感触を得たので，この点につ いては機会を改めて報告したいと考えている.

\section{V 結 論}

昭和61年 1 月の群馬県精神保健センター開所時 から平成 5 年 3 月末までの電話相談記録票から, 複数の情報によって事例を同定し得た電話相談を 選び出し，これらを継続相談と称してその特徵に ついて調査した。その結果以下のことが明らかと なった。

1）電話相談は匿名性が強く,継続相談全てを同 定することは困難であった。

2）継続相談の大半は 4 回までに終結するが, 中 には数年に渡って継続する事例や 100 回以上も継 続している事例が19事例あった。

3）相談内容では「精神障害の問題」が最も多く, ついで「児童生徒の問題」が多かった。

4）「精神障害の問題」を細かくみていくと，「精 神障害ではないかとの心配」「精神障害の治療の問 題」「社会復帰の問題」という治療段階の進展に 伴って, 精神科治療歷を有する者についての相談 が増加した。

5）継続相談事例は,複数の医療機関や相談機関 を訪れてもなお解決できない困難な問題を抱えて 困惑していた.

6）継続相談事例は当センターに対する安心感 や親近感，あるいは相談のしやすさから継続的に 電話をかけていた。

以上述べた点については，当センターが電話相 
談にも来所相談にも無料で応じる公的相談機関で あることを PRしている点，特に電話相談は随時 受けつけるとうたっていることが影響していると 考えられた。

\section{文献}

有田モト子（1993）：電話相談における頻回通話者へ の理解と対応, 精神保健シリーズ第26集, 37-57, 栃 木県精神保健センター

有田モト子, 小室康平 (1986)：常習的通話, 日本い のちの電話連盟編，電話による援助活動一いのちの 電話の理論と実際, 190-201, 学事出版 (東京)

有田モト子，長谷川浩一（1994）：コミュニティ心理 臨床における専門家の活動一ボランティア電話相談 に対する支援，心理臨床学研究，11，278-284

藤竹 䀘 (1989)：現代生活と電話, 電話相談学研究, $1,1-6$

長谷川浩一 (1992)： 電話相談のなすべきこと，でき ること一電話相談心理学の提言, 電話相談学研究, $4,1-10$

長谷川浩一 編集 (1990)： 電話相談の基礎と実際一心 をむすぶカウンセリング，川島書店（東京）

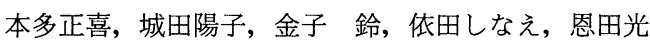
代, 高橋 滋 (1994)： 精神保健センターにおける 電話相談の実態について一開所から平成 3 年度末ま
での統計から，民族衛生，60，44-55

稲村 博 (1979)： いのちの電話における面接相談, 社会福祉法人いのちの電話編, いのちの電話一電話 相談の理論と実際, 131-139, 学事出版 (東京) 石原幸夫, 桜井素子, 伊東秀行 (1991)：精神保健セ ンターにおける心の電話相談に関する研究, 電話相 談学研究, 3, 20-27

岩崎律子, 太田省吾, 安藤美由紀, 杉森命久美, 石原 幸夫（1984）：フォローアップ調查からみた精神衛 生電話相談の有効性, 社会精神医学, 7,162

小林三郎（1992）：家庭支援相談等事業の展開とその 考察, 厚生省児童家庭局児童相談事例集第23集, 183 $-193$

多田治夫，田中富士夫 監訳 (1982)： 電話カウンセリ ングの技法と実際一電話相談活動と危機介入，川島 書店 (東京), Lester, D. \& Brockopp, G.W. (1973), Crisis Intervention and Counseling by Telephone, Charles C. Thomas (Springfield)

白井徳満 (1979)：医療相談，社会福祉法人いのちの 電話編，いのちの電話一電話相談の理論と実際, 121 -128 , 学事出版 (東京)

植木ひろ子, 桜井素子, 五十嵐命久美, 石原幸夫 (1981)： 精神衛生センターにおける電話相談の機能分析, 社 会精神医学，4，187-188

（受稿 1994.5.18；受理１994.11.4） 